\title{
PENERAPAN REINVENTING GOVERNMENT (MEWIRAUSAHAKAN BIROKRASI) DI KECAMATAN JEKAN RAYA KOTA PALANGKA RAYA
}

\author{
Community Participation in Development Planning of Banut Kalanaman Village, \\ Katingan Hilir Subdistrict, Katingan District
}

\section{Siren* \\ Irwan Sinaga}

Universitas Muhammadiyah

Palangkaraya, Palangka Raya,

Central Kalimantan, Indonesia

email:

siren@umpalangkaraya.ac.id

\section{Kata Kunci:}

Penerapan

Reinventing Government

Pemerintahan Wirausaha

Keywords:

Application

Reinventing Government

Entrepreneurial Government

Accepted

July 2017

Published

October 2017

\begin{abstract}
Abstrak
Tujuan dari penelitian ini ialah untuk mengetahui penerapan Reinventing Government di Kecamatan Jekan Raya Kota Palangka Raya. Metode yang digunakan dalam penelitian ini yaitu metode penelitian kulitatif, dengan menggunakan teknik pengumpulan data wawancara, dokumentasi, dan observasi. Sumber data dalam penelitian ini adalah Camat beserta jajarannya dan masyarakat di wilayah administratif Kecamatan Jekan Raya. Berdasarkan hasil penelitian menunjukan bahwa penerapan Reinventing Government di Kecamatan Jekan Raya Kota Palangka Raya masih belum dilakukan secara maksimal dan konsisten. Dari kesepuluh prinsip Reinventing Goverment, ternyata hanya tiga prinsip yang telah benar diterapkan yaitu prinsip Berorientasi Pada Hasil, Pemerintahan Antisipatif, dan Pemerintahan Desentralisasi. Ketujuh prinsip lainnya yang belum secara konsisten diterapkan yaitu prinsip Pemerintahan Katalis, Pemerintahan Milik Masyarakat, Pemerintahan Kompetitif, Pemerintahan Berorientasi Misi, Pemerintahan Berorientasi Pelanggan, Pemerintahan Wirausaha, serta Pemerintahan Berorientasi Pasar. Seharusnya pihak kecamatan dapat menumbuhkan minat masyarakat agar dapat aktif berpartispatif dalam program/kegiatan Kecamatan, dapat berinisiatif lebih dulu untuk menggandeng instansi lain mengadakan sosialisasi kepada masyarakat, adanya pegawai yang ditunjuk langsung untuk mengelola kotak saran, dapat memberi tanggapan untuk aspirasi masyarakat, berorientasi pada misi, memberikan pelayanan yang benar-benar prima, mengurangi dan memberantas praktek pungli, lebih cermat lagi dalam melihat potensi-potensi yang lebih produktif, dan memberikan berbagai informasi terkait kecamatan melalui berbagai media.
\end{abstract}

\begin{abstract}
The purpose of this study was to find out the application of the Reinventing Government in the District of Jekan Raya, Palangka Raya City. The method used in this study is a qualitative research method, using interview data collection techniques, documentation, and observation. The data sources in this study were the Sub-District Head and his staff and the community in the administrative area of Jekan Raya Sub-District. Based on the results of the study show that the implementation of the Reinventing Government in Jekan Raya Subdistrict, Palangka Raya City is still not done maximally and consistently. Of the ten Reinventing Government principles, it turns out that only three policies have been correctly implemented, namely the Results-Oriented law, Anticipatory Government, and Decentralized Government. The other seven principles that have not been consistently applied are the principles of Catalyst Government, Community Ownership, Competitive Government, Mission Oriented Government, Customer Oriented Government, Entrepreneurial Governance, and Market-Oriented Government. Subdistricts should be able to foster interest in the community so that they can actively participate in district programs/activities, can take the initiative to collaborate with other agencies to conduct socialization to the community, employees appointed directly to manage suggestion boxes, can respond to community aspirations, are mission-oriented, providing truly excellent services, reducing and eradicating extortion practices, more carefully in seeing more productive potentials, and providing various information related to sub-districts through multiple media.
\end{abstract}

\section{PENDAHULUAN}

Pembaharuan sistem birokrasi ini ialah mentranformasikan sistem bisnis di perusahaan swasta ke dalam sistem birokrasi sebuah negara yang dinamakan dengan Reinventing Government (Mewiraswastakan Birokrasi). Dalam konsep ini pula, para aparatur negara bukan diartikan menjadi seorang 
pengusaha yang harus berdagang. Melainkan adanya suatu upaya dari para aparatur tersebut untuk senantiasa bekerja keras dan bekerja cerdas dalam melihat sumber-sumber yang berpotensi ekonomi di daerahnya agar yang tidak produktif menjadi produktif, dan yang produksinya rendah mampu lebih ditingkatkan keproduksi yang tinggi.

Namun sayang pada kenyataannya pemerintah masih belum mampu menyediakan dan memberikan pelayanan yang benar-benar memuaskan dan memenuhi kebutuhan pelanggannya yaitu masyarakat. Masih terdapat sistem birokrasi yang berbelit-belit, proses pelayanan yang membutuhkan waktu cukup lama, kurang responsif terhadap masyarakat yang dilayani, aparatur yang kurang disiplin, bahkan terkadang praktek pungutan liar (Pungli) masih bisa terjadi saat berurusan dengan berbagai pelayanan pemerintahan. Sehingga tercatat metode ini sudah cukup lama dibandingkan dengan metode-metode yang muncul di era modern saat ini. Walaupun tebilang cukup lama, namun metode ini masih sangat ideal jika diterapkan di negara Indonesia. Hal ini disebabkan karena birokrasi pemerintahan di Indonesia sampai saat ini masih banyak terdapat birokrasi yang bersifat kaku, kurang efisien, dan sistem administrasi yang rumit. Oleh karena itu, penerapan Reinventing Government dirasa cocok untuk mengubah sistem birokrasi pemerintahan sebelumnya.

Hampir semua instansi di Indonesia ini mengalami masalah klasik seperti di atas. Baik dari instansi pusat hingga instansi yang ada di daerah. Tidak terkecuali instansi-instansi yang ada di Kota Palangka Raya, yaitu ibu kota dari provinsi Kalimantan Tengah, terutama pada lingkup kecamatan. Salah satu kecamatan di Kota Palangka Raya ialah Kecamatan Jekan Raya, yang mana menurut Badan Pusat Statistik Kota Palangka Raya tahun 2016 mengemukakan bahwa Kecamatan Jekan Raya adalah kecamatan terluas ke empat setelah Kecamatan Rakumpit, Sabangau, dan Bukit Batu. Walaupun kecamatan ini terbilang lebih kecil dibanding ke tiga kecamatan lainnya, namun jumlah penduduk di Kecamatan Jekan Raya menduduki urutan pertama terbanyak di Kota Palangka Raya, yaitu berjumlah I 35.129 jiwa atau sekitar 52 \% dari jumlah keseluruhan penduduk di Kota Palangka Raya. Oleh sebab itu, akan sangat berpotensi menimbulkan berbagai problema di dalam kehidupan bermasyarakat. Dengan demikian tugas pelayanan dari Kecamatan Jekan Raya kepada masyarakatnya pun akan benar-benar komplek dan memiliki tanggung jawab yang besar sehingga prinsip reinventing government memang sangat cocok jika diterapkan secara sungguh-sungguh dan konsisten dalam proses birokrasi di Kecamatan Jekan Raya.

Reinventing Government dapat pula diartikan sebagai pembaharuan birokrasi. Arti pembaharuan dalam hal ini menurut Peter Plastrik \& David Osborne (200I) ialah: "Transformasi sistem dan organisasi pemerintah secara fundamental guna menciptakan peningkatan dramatis dalam efektifitas, efisiensi, dam kemampuan mereka untuk melakukan inovasi. Transformasi ini dicapai dengan mengubah tujuan, sistem insentif, pertanggung jawaban, struktur kekuasaan, dan budaya sistem dan organisasi pemerintah". Kemudian Thoha (20I4) seorang ahli administrasi negara menjelaskan bahwa istilah ini sebenarnya sama halnya dengan upaya untuk melakukan pembaruan di bidang birokasi pemerintah. Ada pun sepuluh prinsip yang digagas oleh David Osborn dan Ted Gaebler (2014) dalam karya bukunya yang berjudul Reinventing Government: Mewirausahakan Birokrasi, ialah sebagai berikut:

I. Katalis

2. Milik Masyarakat

3. Kompetitif

4. Digerakan Oleh Misi

5. Berorientasi Hasil

6. Berorientasi Pelanggan

7. Wirausaha

8. Antisipatif

9. Desentralisasi 


\section{Berorientasi Pasar}

\section{METODOLOGI}

Dalam penelitian ini penulis menggunakan metode kualitatif yang mana penulis ingin meneliti lebih dalam tentang penerapan reinventing government pada kantor Kecamatan Jekan Raya, Kota Palangka Raya. Sehingga dalam penelitian kualitatif gejala bersifat holistik atau menyeluruh dan tidak dapat dipisah-pisahkan sehingga tidak atau menetapkan penelitiannya berdasarkan variabel penelitian, sehingga peneliti kualitatif tidak akan menetapkan penelitian hanya berdasarkan variabel penelitian, tetapi keseluruhan Situasi Sosial yang diteliti yang meliputi aspek tempat (place), pelaku (actor), dan aktivitas (activity) yang berinteraksi secara sinergis (Sugiyono, 20II).

\section{HASIL DAN PEMBAHASAN}

Dari hasil penelitian baik dengan menggunakan teknik wawancara, dokumentasi, dan observasi yang dilakukan di lapangan, maka penulis merasa ada beberapa hal yang perlu diperhatikan tekait penerapan prinsip reinventing government di Kecamatan Jekan Raya. Belum optimalnya penerapan prinsip ini atau terkesan masih "setengah hati" dan tidak sungguh-sungguh dalam menerapkannya sehingga ada beberapa prinsip tidak bisa berjalan dengan maksimal. Berdasarkan hasil penelitian ini, terlihat bahwa prinsip-prinsip reinventing government telah diterapakan dalam sistem administrasi di kantor Kecamatan Jekan Raya. Hanya saja dalam penerapan setiap prinsip ini belum dilakukan dengan sungguh-sungguh dan menyeluruh sehingga hasil atau dampak positif dari penerapan prinsip reinventing government ini belum benar-benar dapat tercapai.

\section{Pemerintahan Katalis}

Pemerintahan katalis dalam prinsip reinventing government ialah menempatkan pemerintah hanya sebagai pengarah, bukan sebagai pelaksana langsung dari semua hal teknis pelayanan kepada masyarakat. Sehingga tujuan dalam penyampaian program/kegiatan kepada masyarakat tidak sepenuhnya sampai kepada seluruh masyarakat yang berada di lingkungan Kecamatan Jekan Raya. Hal inipun menjadi kendala untuk terciptanya pemerintahan yang benar-benar katalis. Kendala yang lain, ialah kurangnya partisipasi dari masyarakat untuk mengikuti sosialisasi yang diadakan oleh pihak Kecamatan Jekan Raya.

Pemerintahan Milik Masyarakat

Maka dengan hal itu, masyarakat diberdayakan agar dapat mengontrol pelayanan pemerintahan yang diberikan kepada mereka. Sesuai dengan teori di atas, pihak kecamatan telah benar menerapkan prinsip yang ke dua ini. Namun sayangnya sekali lagi penerapannya belum benar-benar maksimal. Terkait prinsip ke dua ini, pihak kecamatan telah menyediakan kotak saran untuk masyarakat, agar masyarakat yang mengeluhkan pelayanan yang diberikan oleh pihak kecamatan dapat memberikan sumbangsih saran atau kritik. Namun hal tersebut ternyata belum berjalan dengan maksimal juga. Semua usulan dan aspirasi masyarakat masih terabaikan.

\section{Pemerintahan Yang Kompetitif}

Terkait dengan hal itu, pihak kecamatan telah menerapkannya melalui sebuah kompetisi atau perlombaan kebersihan tingkat RT hingga Kelurahan di mana masyarakatlah yang menjadi pesertanya. Hal ini bertujuan agar terciptanya lingkungan yang bersih, indah, rapi, dan sehat melalui persaingan di lingkungan masyarakat. Namun proses kompetisi ini bisa dikatakan masih belum dapat berjalan sesuai dengan tujuan karena adanya kendala-kendala di masyarakat sebagai peserta dan pihak kecamatan sebagai penyelenggara. Oleh sebab itu prinsip ke tiga inipun ternyata belum bisa diterapkan dengan maksimal pada kantor Kecamatan Jekan Raya.

\section{Berorientasi Misi}

Prinsip berikutnya pada reinventing government ialah pemerintahan yang berorientasi pada misi, maksudnya 
ialah menempatkan peranan misi pada prioritas pelaksanaan proses birokrasi. Pada misi ini pihak kecamatan masih bisa dikatakan berhasil membawa masyarakatnya untuk hidup berdampingan dan saling mewujudkan kerukunan. Dari semua misi yang ada di kantor Kecamatan Jekan Raya, sebagian masih belum bisa tercapai, sehingga dalam prinsip ini penerapannyapun dirasa belum maksimal juga.

\section{Berorientasi Hasil}

Dalam prinsip pemerintahan yang berorietasi hasil para wirausaha selalu mendapati lembaga-lembaga yang berkinerja kurang bagus jika lembaga tersebut lebih memprioritaskan masukan dibanding hasil. Dengan begitu prinsip berorientasi hasil di Kecamatan Jekan Raya telah diterapkan dengan benar dan telah dirasakan dampak positif dari penerapan prinsip ini yang berupa para pegawai di bawah camat, akan berusaha semaksimal mungkin untuk menyelesaikan tugas dan kewajibannya.

\section{Berorientasi Pelanggan}

Kaitannya dengan prinsip berorientasi kepada pelanggan, pihak Kecamatan Jekan Raya telah berhasil memberikan kepuasan untuk beberapa layanan yang mereka sediakan bagi masyarakat. Namun terkait hasil musrenbang yaitu di mana musrenbang adalah harapan masyarakat agar aspirasinya dapat terpenuhi, tetapi nyatanya aspirasi masyarakat tersebut masih hanya menjadi sebuah harapan yang tidak tahu kapan akan terealisasi.

\section{Pemerintahan Wirausaha}

Pada prinsip yang ketujuh dari reinenting government ini, pemerintah dituntut untuk cermat dalam melihat potensi-potensi sumber daya yang dapat diunggulkan yang berada tepat di daerahnya. Dengan demikian prinsip pemerintahan wirausaha ternyata belum pula diterapkan secara maksimal. Karena belum ada upaya sungguh-sungguh dari pihak kecamatan untuk lebih cermat melihat potensi-potensi yang dapat diciptakan di Wilayah Kecamatan Jekan Raya.

Pemerintahan Antisipatif

Berdasarkan hal tersebut, maka pihak kecamatan cukup antisipatif untuk menjalankan proses layanan serta menciptakan pegawai yang disiplin dan koperatif dalam menjalankan tugas dan tanggung jawabnya sebagai abdi negara.

\section{Pemerintahan Desentralisasi}

Pemerintahan desentralisasi ialah sebuah strategi pemerintahan wirauasaha untuk membagikan wewenang baik dari atasan kepada bawahan ataupun dari pemerintah kepada masyarakat. Prinsip pemerintahan desentralisasi ini telah juga diterapkan pada kantor Kecamatan Jekan Raya.

Pemerintahan Berorientasi Pasar

Pada prinsip ini, pemerintah dapat memberikan berbagai informasi kepada masyarakat baik berbagai pelayanan yang disediakan oleh pemerintah atau program apa saja yang akan dilaksanakan oleh pihak pemerintah. Berkaitan dengan hal tersebut, hasil wawancara dengan pihak Kecamatan Jekan Raya menyebutkan bahwa pihak mereka belum sepenuhnya melakukan hal tersebut. Baik informasi melalui website maupun media yang lainnya. Adapun mereka hanya mengandalkan spanduk yang dipasang di depan kantor kecamatan bila ada program/kegiatan yang baru. Namun seiring perkembangan jaman, media internet sangat efektif untuk memberikan informasi-informasi dari pihak kecamatan. Namun hal tersebut belum benar-benar diterapkan karena kendala pertama ialah keterbatasan sumberdaya manusianya.

\section{KESIMPULAN}

Dalam penerapan prinsip pemerintahan katalis, sosialisasi setiap program/ kegiatan masih dirasa kurang karena pihak kecamatan belum mampu menumbuhkan 
peran partisipasi masyarakat serta kurangnya upaya untuk menyebarkan informasi tentang adanya sosialisasi kepada masyarakat. Kemudian pada prinsip ke dua yaitu pemerintahan milik masyarakat, pihak kecamatan juga belum menerapkannya dengan baik. Kotak saran disediakan, namun pengelola kotak saran tidak ada serta musrenbang hanya sebagai formalitas penyerap aspirasi masyarakat. Selanjutnya pada prinsip pemerintahan kompetitif, pihak kecamatan belum mampu mensosialisasikan secara menyeluruh terhadap masyarakat dan belum mampu juga menarik minat masyarakat untuk berpartisipasi dalam ajang lomba yang dibuat oleh pihak kecamatan. Oleh sebab itu prinsip ini pun belum diterapkan secara sungguh-sungguh. Pada prinsip ke empat yakni pemerintahan berorientasi misi, ternyata didapati hanya satu misi saja yang dapat terwujud. kemudian untuk orientasi mewujudkan misi yang lainnya, pihak kecamatan masih belum memprioritaskan misi yang lain agar dapat tercapai. Berorientasi pada hasil, pada prinsip ini pihak kecamatan telah benar menerapkannya pada sistem birokrasi di kantor Kecamatan Jekan Raya. Hal ini dapat terlihat dengan adanya pemberian penghargaan yang dilakukan oleh atasan kepada bawahan atas prestasi kerja mereka. Kemudian pada prinsip ke enam yaitu berorientasi pelanggan, pihak kecamatan masih belum menerapkannya dengan sungguh-sungguh. Karena hasil aspirasi masyarakat pada musrenbang belum juga terealisasikan sepenuhnya. Pemerintahan wirausaha, bisa dikatakan telah diterapkan pada Kecamatan Jekan Raya namunbelum benar-benar maksimal, karena beberapa potensi di wilayah kecamatan belum benarbenar digali. Baik potensi pariwisata yang masih sebatas wacana, serta belum ada dukungan yang maksimal untuk para wirausahawan UKM di wilayah Kecamatan Jekan Raya. Baik berupa dukungan melalui pembinaan, pemberdayaan, seminar, serta modal kerja. Pihak kecamatan telah pula menerapkan prinsip antisipatif dengan benar. $\mathrm{Hal}$ ini telah diterapkan melalui ketegasan seorang atasan kepada bawahannya serta pelayanan yang diberikan oleh pihak Kecamatan Jekan Raya kepada masyarakat sebagai pelanggannya. Dalam prinsip pemerintahan desentralisasi, pihak kecamatan juga telah menerapkannya dengan benar dan sungguhsungguh. Hal itu dapat terlihat dengan adanya pembagian wewenang dari atasan kepada bawahan serta dari pihak kecamatan kepada masyarakat. Pihak Kecamatan Jekan Raya belum menerapkannya secara maksimal. Hal itu dapat terlihat dari belum adanya upaya sungguh-sungguh dari pihak kecamatan untuk memberikan berbagai informasi kepada masyarakat melalui berbagai aspek serta menggunakan berbagai media.

\section{REFERENSI}

Afifuddin dan Beni Ahmad Saebani. 2013. Metodologi Penelitian Kualitatif. Bandung: Pustaka Setia.

Bernardianto, R.B., Mulyani, S. 2016. Implementasi Kebijakan Pengelolaan Dana Bantuan Operasional Sekolah (BOS) dalam Rangka Peningkatan Manajemen Sekolah di Madrasah Tsanawiyah 2 Palangka Raya. Pencerah Publik. $3(1): 13-25$.

Hoadley, Mason C. 2006. Quo Vadis Administrasi Negara Indonesia: Antara Kultur Lokal Dan Struktur Barat. Yogyakarta: Graha Ilmu.

Idrus, Muhammad.2009. Metode Penelitian Ilmu Sosial: Pendekatan Kulitatif dan Kuantitatif. Jakarta: Erlangga

Kalteng Pos. 2017. Tak Punya Produk Unggulan. I4 Maret 2017, hal 2.

Karyadi, K., Siren, S. 2016. Analisis Kinerja Pelayanan Terpadu Untuk Perizinan Usaha Di Kabupaten Katingan. Pencerah Publik. 3(I):4352.

Lisnawati, L., Abdullah, M., Noknah, Z. 20l4. Peran Komunikasi Antrpersona Dan Kinerja Aparatur Pemerintah Desa Terhadap Pembangunan Infrastruktur Desa Sungai Kayu Kecamatan Kapuas Barat Kabupaten Kapuas. Al Kalam Jurnal Komunikasi, Bisnis dan Manajemen. I(2):4.

Muhammad, Fadel. 2008. Reinventing Local Government: Pengalaman Dari Daerah. Jakarta: PT. Elex Media Komputindo 
Osborn, David dan Ted Gaebler. 2014. Mewirausahakan Birokrasi: Reinventing Government. Jakarta: Pustaka Binaman Pressindo.

Plastrik, Peter dan David Osborne. 200I. Memangkas Birokrasi: Lima Strategi Menuju Pemerintahan Wirausaha. Jakarta: Teruna Grafica.

Rosidi, Abidarin dan Anggraeni Fajriani. 2013. Reinventing Government: Demokrasi dan Reformasi Pelayanan Publik. Yogyakarta: Andi.

Thoha, Miftah. 20II. Ilmu Administrasi Publik Kontemporer. Jakarta: Prenada Media Group

Toun, N.R., Candra, E.S. 2016. Model Perumusan Kebijakan Elit Transformasional Pada Perencanaan Pembangunan Masyarakat (Studi Perencanaan Pembangunan Di desa Tumbang Liting). Pencerah Publik. 3(2):9- I8.

Sugiyono. 201I. Metode Penelitian Kombinasi (Mixed Methods). Yogyakarta: Alfabeta.

Suryana, Yuyus dan Kartib Bayu. 2013. Kewirausahaan: Pendekatan Karakteristik Wirausahawan Sukses (Edisi 2). Jakarta: Prenada Media Group

Wasistiono, Sadu, 2009. Perkenbangan Organisasi Kecamatan Dari Masa Ke masa. Bandung: Fokusmedia.

Zukarnaini. 2013. Reinventing Kelembagaan Pemerintah Daerah Yang Ramping Dan Efesiensi. Jurnal Ekonomi. 2 I (4): I-6. 